\title{
PERFILES
}

\section{Poetas y Prosistas de América: Walt Whitman}

QU nombre, Walter, fué abreviado en Walt. En la magnífica edi$\$$ ción de Leaves of grass editada en Filadelfia por David MacKay -tomo de 562 páginas-, se inserta en facsímile manuscrito, de gruesos trazos, la autobiografía del poeta, nacido el 31 de mayo de 1819, en West Hills, cerca de Huntington, en Long Island (Estado de New York). De su padre, carpintero, recibió sangre británica; de su madre, la herencia aventurera de abuelos marineros, holandeses. Vivió Walt st infancia en Brooklyn, frente a la fiebre naciente de un Manhattan que se iba gestando confusamente en ansias y realizaciones de progreso.

$\mathrm{Su}$ amor por el pueblo, por los seres sencillos, anónimos, humildes, esforzados, quedó siempre evidenciado en toda su vida, llena de pasajes de honda solidaridad humana. Bastaría recordar el espíritu tan generoso y sacrificado con que, durante la guerra de secesión, atendió a numerosísimos heridos, que lo bendecían desde la tristeza de los hospitales.

Tipógrafo y periodista, este inmenso poeta supo aceptar siempre la tarea cotidiana, con la sonrisa en los labios. Ciertamente, la tipografía y el periodismo no fueron las únicas labores de su vida. También anduvo en un negocio de ventas de casas y ocupó algún cargo oficinesco gubernamental.

Publicó un solo libro de poemas: el ya mencionado Leaves of grass, cuya primera edición apareció en 1885. Aquel tomo de apenas 
95 páginas no obtuvo, en su patria, el éxito que podría suponer quien, no advertido de lo acaecido entonces, leyera las páginas admirables de Leaves of grass. Se sabe, por ejemplo, que, exceptuando a Emerson, Walt fué poco apreciado por sus conterráneos. Se le valoró más en Inglaterra, especialmente por artistas de la talla de Swinburne, Rossetti y Symons. En prosa, Walt dejó algunas obras de valor desigual, entre ellas Democratic Vistas (1871). Su gran libro, su gran mensaje, fué Leaves of grass.

La poesía whitmaniana tuvo algo de ciclón saludable en los jardines ya mustios del romanticismo. Sin embargo, a nuestro juicio, lo que más ha trascendido de este poeta, entre nosotros, no es lo fundamental de su obra. Releyendo las páginas de Leaves of grass valoramos, sobre todo, aspectos poco difundidos del humanísimo poeta: la sobriedad de su estilo, la esencialidad de ciertos poemas brevísimos, a manera de inscripciones lapidarias, su don de auténtico poeta, al hallar motivos de canto en los aspectos más humildes de la vida cotidiana. Los poemas suyos que mejor se han difundido en el ambiente, son, por lo general, los de tono exaltado, a veces altisonante.

Whitman fué un autodidacta, un maravilloso ejemplo de fuerza creaclora y dinamismo.

Hay indicios que dan derecho a suponer que Leaves of grass no fué, precisamente, su obra inicial en poesía. Parece que anteriormente había escrito varios libros de versos, definitivamente perdidos, y de un carácter muy distinto a éste, del verso libre, anchuroso y saludable de Leaves of grass. Y es que, bajo la apariencia de improvisación de los mejores poemas whitmanianos, hay una madurez adquirida en un ejercicio poético que de ninguna manera amenguaba su espontaneidad.

Entre los signos de nuestra época, uno es indudable: la revaloración de Whitman, su redescubrimiento. Sin duda, en este acontecer no entran sólo los valores poéticos, sino también el hecho de que Whitman vió siempre en América el Continente de la Democracia, y hoy es justo que ese Continente vea en él a su símbolo, símbolo también de nuestra fe y de nuestra ardentía. Como muy bien afirma Babette Deutsch - la aguda escritora estadounidense-, "Walt quería ser un poeta, pero no quería escribir versos azucarados, en los viejos, rancios temas". Y también ha subrayado Babette las luchas que Whitman tuvo para lograr el reconocimiento de la crítica y del público, reconocimiento escasamente logrado en vida. Recuerda a 
Walt, pasando frente a la Casa Blanca. Descle su ventana, Lincoln ve la fuerte figura del poeta de Manhattan. "-iQuién es?", pregunta el Presidente a su compañero. "-Walt Whitman", le contesta. "-Bien", responde Lincoln, "he looks like a MaN."

La influencia de Whitman - su apostolado estético y humano- se ha ejercido, sobre todo, en el espíritu de su pueblo, en algunos aspectos morales de la psicología estadounidense. De los grandes poetas surgidos en su patria, sólo Carl Sandburg puede ser señalado, en cierta manera, como un continuador de Whitman, a quien supera en algún aspecto estético. Los otros poetas han seguido rutas distintas.

El hecho de que muy autorizados exégetas señalen a Whitman como el mayor poeta de América, y que otros críticos imparciales y serenos den ese título a Poe, no deja de ser interesante, ya que llegaríamos a la conclusión de que Estados Unidos -el país que durante tanto tiempo fué considerado "antipoético" por excelencia- ha dado al mundo los dos mayores poetas del Nuevo Continente. Corresponde igualmente señalar que la estadounidense Emily Dickinson - maravillosa criatura, comparable a nuestra Delmira - fué contemporánea de Whitman, de Walt Whitman van Velsor, fallecido en 1892, en su casita de Candem (N. J.)

En América Latina, el espíritu más afín con Whitman es, a nuestro parecer, el del gran poeta brasileño Ronald de Carvalho, fallecido en 1935. En el poeta de "Toda América" hay una visión neowhitmaniana, surgida, más que de una influencia literaria, de tuna hermandad temperamental, de una resonancia de alma y de americanidad. Debemos destacar también que - si bien es cierto que la obra de Ronald de Carvalho no posee el sentido precursor de la de Whitman, ni su vigor expresional- opinamos que el lírico brasileño supera al estadounidense en intensidad emocional $y$, muchas veces, en poder de imaginación, siendo menos conceptual -más depurado, líricamente- que Walt.

E1 hecho de que Whitman no haya dejado un heredero de su arte sería, en definitiva, una resultante de su propia genialidad, grandeza solitaria, voz que nunca se repite, pasión que sólo una vez estremece el corazón del mundo. 
